\title{
Hydrologic responses to earthquakes and a general metric
}

\author{
CHI-YUEN WANG AND MICHAEL MANGA \\ Department of Earth and Planetary Science, University of California, Berkeley, CA, USA
}

\begin{abstract}
Hydrologic responses to earthquakes, including liquefaction, changes in stream and spring discharge, changes in the properties of groundwater such as geochemistry, temperature and turbidity, changes in the water level in wells, and the eruption of mud volcanoes, have been documented for thousands of years. Except for some water-level changes in the near field which can be explained by poroelastic responses to static stress changes, most hydrologic responses, both within and beyond the near field, can only be explained by the dynamic responses associated with seismic waves. For these responses, the seismic energy density e may be used as a general metric to relate and compare the various hydrologic responses. We show that liquefaction, eruption of mud volcanoes and increases in streamflow are bounded by $e \sim 10^{-1} \mathrm{~J} \mathrm{~m}^{-3}$; temperature changes in hot springs are bounded by $e \sim 10^{-2} \mathrm{~J} \mathrm{~m}^{-3}$; most sustained groundwater changes are bounded by $e \sim 10^{-3} \mathrm{~J} \mathrm{~m}^{-3}$; geysers and triggered seismicity may respond to seismic energy density as small as $10^{-3}$ and $10^{-4} \mathrm{~J} \mathrm{~m}^{-3}$, respectively. Comparing the threshold energy densities with published laboratory measurements, we show that undrained consolidation induced by dynamic stresses can explain liquefaction only in the near field, but not beyond the near field. We propose that in the intermediate field and far field, most responses are triggered by changes in permeability that in turn are a response to the cyclic deformation and oscillatory fluid flow. Published laboratory measurements confirm that changes in flow and time-varying stresses can change permeability, inducing both increases and decreases. Field measurements in wells also indicate that permeability can be changed by earthquakes in the intermediate field and far field. Further work, in particular field monitoring and measurements, are needed to assess the generality of permeability changes in explaining far-field hydrologic responses to earthquakes.
\end{abstract}

Key words: liquefaction, permeability change, triggered seismicity, geysers, mud volcanoes

Received 22 July 2009; accepted 21 October 2009

Corresponding author: Chi-Yuen Wang, Department of Earth and Planetary Science, University of California, Berkeley, CA, USA.

Email: chiyuen@berkeley.edu. Tel: (510) 642-2288. Fax: (510) 643-9980

Geofluids (2010) 10, 206-216

\section{INTRODUCTION}

Over the past two thousand years, a large variety of hydrologic changes following earthquakes has been documented. Examples include liquefaction of soils, changes in the eruption behavior of mud volcanoes and geysers, the formation of new springs, disappearance of previously active springs, increased discharge in streams, and changes in the properties of groundwater such as color, temperature, composition and water pressure (e.g., Montgomery \& Manga 2003). It is not unexpected that earthquakes can cause hydrologic changes because the stresses created by earthquakes can be large compared to other time-varying stresses. What is surprising are the large amplitudes of hydrologic responses and the great distances over which these changes occur: our focus in this paper are hydrologic responses at such large distances.

Hydrologic responses to earthquakes are not just curiosities: because earthquakes and water interact with each other through changes in both stress and physical properties of rocks, understanding the origin of hydrological responses can provide new insights into hydrogeologic and tectonic processes at scales in space and time that are otherwise difficult to study. Besides being a matter of academic interest, the study of earthquake-induced hydrologic changes also has important implications for water resources and engineering enterprise. For example, groundwater level changes following earthquakes can affect water supplies (Chen \& Wang 2009) and it is sometimes necessary to evaluate the causative role of an earthquake in insurance 
claims for loss of water supply (Roeloffs 1998). Forensic earthquake hydrology was also applied to evaluate whether an earthquake may have played a causative role in the 2006 eruption of a mud volcano eruption in the Indonesian city of Sidoarjo, in eastern Java, that led to massive destruction of property, infrastructure and evacuation of people (Manga 2007). Debate on the role of an earthquake in this mud volcano continues (Mazzini et al. 2007; Davies et al. 2008). Groundwater level changes following earthquakes may also put some underground nuclear waste repositories at risk (Carrigan et al. 1991; Roeloffs 1998). Earthquake-induced fluid pressure changes can initiate liquefaction of the ground that in turn causes great damage to engineered structures (e.g., Seed \& Lee 1966), affect oil well production (Beresnev \& Johnson 1994), and sometimes trigger seismicity (Hill \& Prejean 2007). Finally, measured changes of the pore pressure in rocks and/or the chemical composition of groundwater are sometimes taken as signatures of the crustal response to tectonic deformation (e.g., Davis et al. 2001) or even as earthquake precursors (e.g., Silver \& Wakita 1996).

Earthquakes cause both static and dynamic (shaking) changes of the stress in the crust. Both types of stress change decrease with increasing distance from the earthquake, but at different rates. For example, the peak amplitude of the time-dependent change in the Coulomb failure stress (peak $\Delta \mathrm{CFS}(t)$ ) diminishes much less rapidly with distance than the static change $(\triangle \mathrm{CFS})$ in the same stress (e.g., Kilb et al. 2002). Thus at close distances the ratio (peak $\Delta \mathrm{CFS}(t)) / \Delta \mathrm{CFS}$ is approximately proportional to the source-receiver distance, $r$, and at larger distances proportional to $r^{2}$ (Aki \& Richards 1980). At distances up to $\sim 1$ ruptured fault length, the static and the peak dynamic changes are comparable in magnitude, while at distances greater than a few ruptured fault lengths, the peak dynamic change is much greater than the static change. The relative magnitude of static and dynamic stresses is reflected in the hydrologic responses to earthquakes and is critical to understanding the origin of hydrological changes. Hereafter we use the expression 'near-field' to denote distances up to $\sim 1$ ruptured fault length, 'far-field' to denote distance many times greater than the ruptured fault length, and 'intermediate-field' for distance in between.

In the past two decades, there have been rapid development and deployment of geophysical and hydrological instruments around the globe. The number and especially the quality of documented hydrological responses to earthquakes have expanded rapidly, which, in turn, have stimulated more detailed analysis and hypothesis testing. Here we use a common metric, the seismic energy density, to relate the variety of hydrologic responses with each other and, at the same time, to compare the dissipated energy for the hydrologic responses with that measured in laboratory experiments so that some physical constraints may be provided in the discussion and hypothesis testing of the triggering mechanism of the hydrologic responses. For a more complete discussion of this general topic we refer readers to a volume by Wang \& Manga (2010). An earlier and more brief review on the general topic of earthquake hydrology is also available in Manga \& Wang (2007).

\section{OBSERVATIONS}

In Fig. 1 we compile observations of hydrologic responses to earthquakes for several classes of phenomena: liquefaction, changes in streamflow, changes in spring temperature, changes in eruption behavior of geysers, and the eruption of mud volcanoes and magmatic volcanoes. The sources of these observations and data are numerous and we have tabulated them in Table 1, and many are described in more detail in Wang \& Manga (2010). These data come from the refereed literature or are based on readily accessed archival data.

As noted by many authors (e.g., Mogi et al. 1989; Roeloffs 1998; King et al. 1999; Manga \& Wang 2007; Wang \& Chia 2008), the distribution of a variety of hydrologic responses may be scaled by the earthquake magnitude $M$ and distance $r$ from the earthquake source. These parameters, i.e., $r$ and $M$, are used to characterize the occurrences of hydrologic responses because the majority of

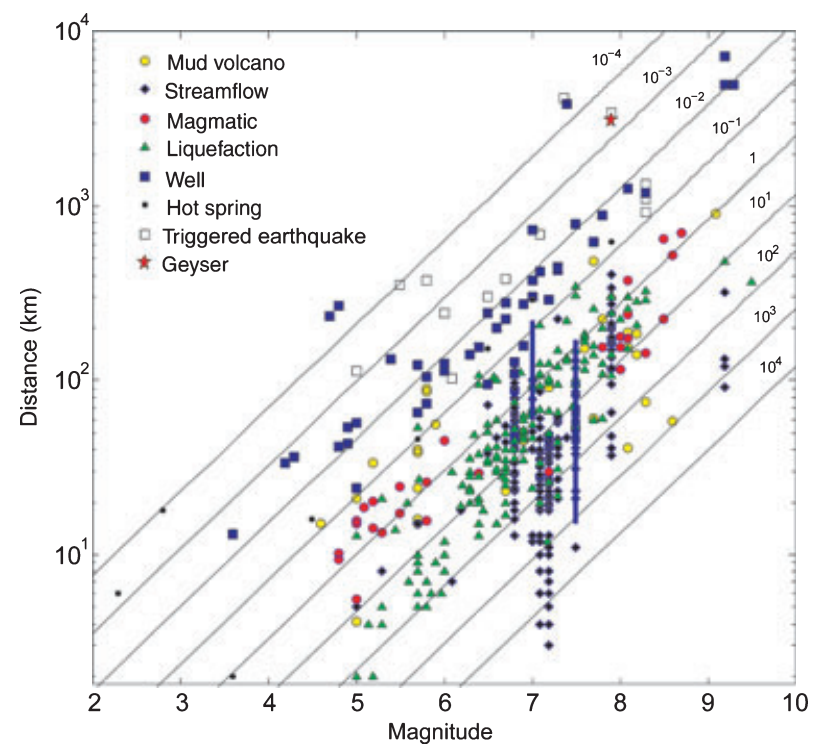

Fig. 1. Distribution of earthquake-triggered hydrologic changes as a function of earthquake magnitude and distance. Also plotted are the $\log r$ versus $M$ contours of constant seismic energy density $e$, which is the seismic energy in a unit volume in the seismic wave train; it thus represents the maximum seismic energy available to do work at a given location during the earthquake. No distinction is made among the different magnitude scales because the majority of documentations (many historical) do not note such distinction. For comparison purposes, we also plot earthquake-induced magmatic volcanic eruptions. Data and sources are listed in Table 1. 
Table 1 Features of earthquake triggered hydrologic phenomena.

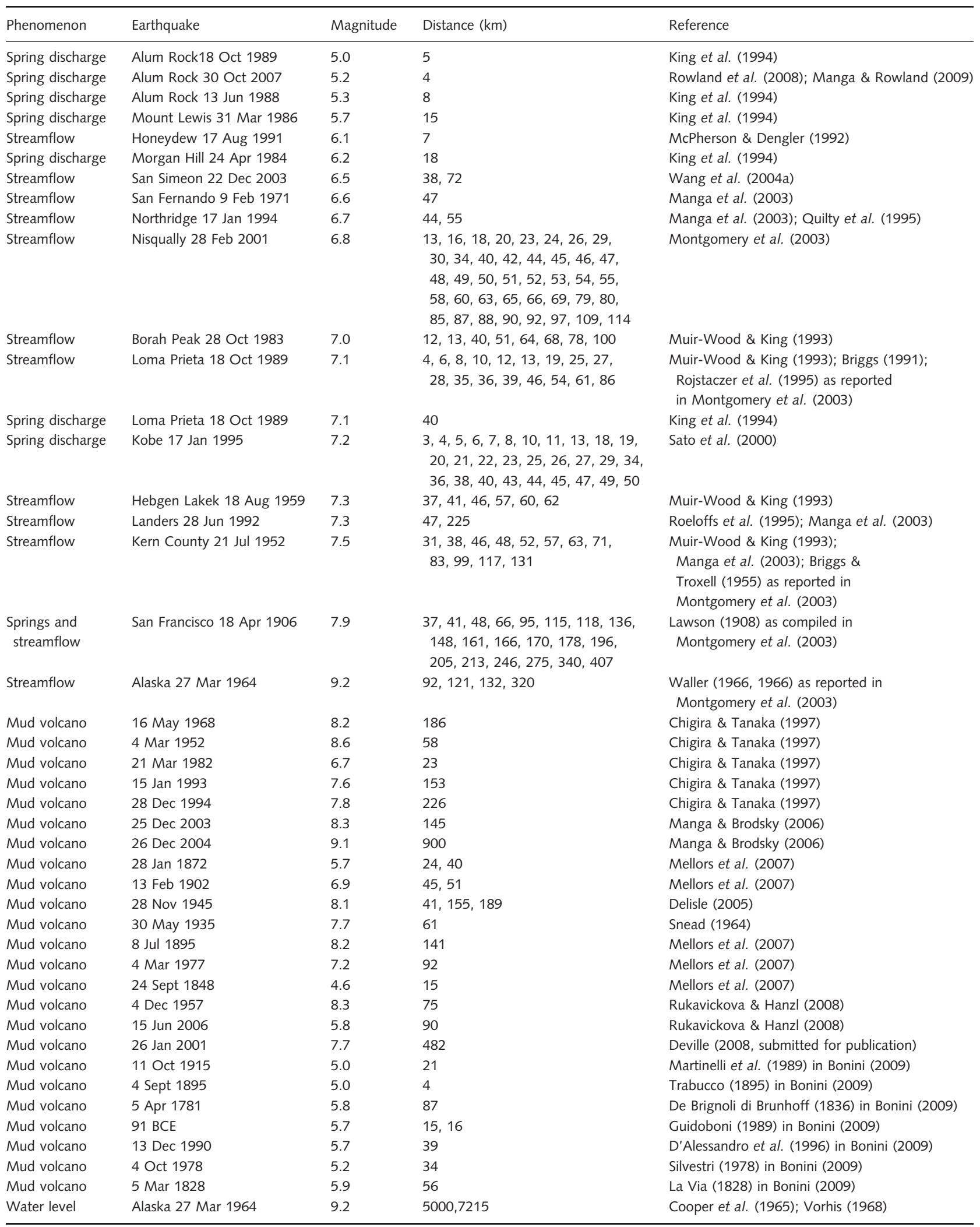


Table 1 (Continued)

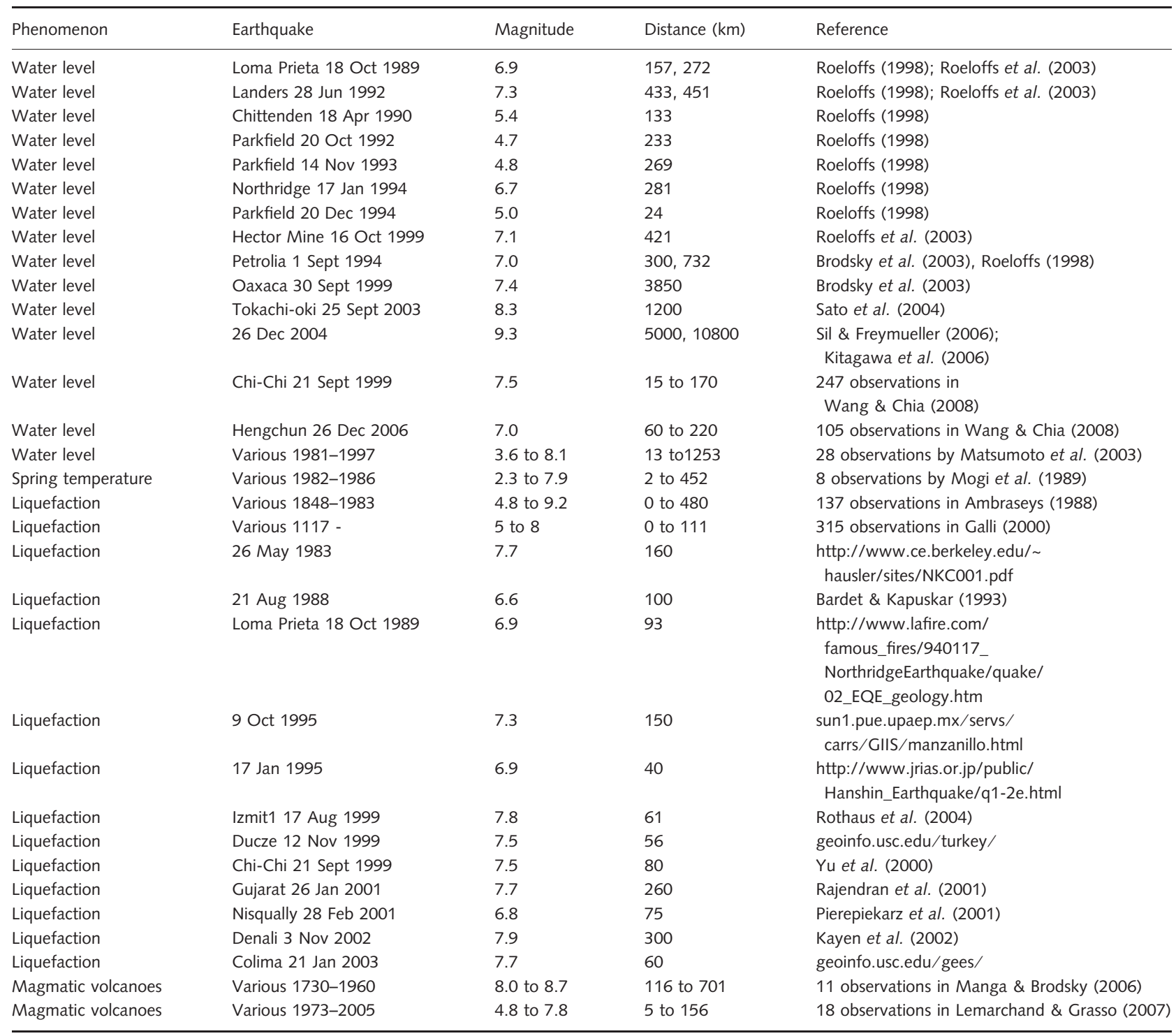

documentations (many historical) do not note the style of faulting, the directivity of fault rupture, or the distance to the ruptured fault, nor do they make a distinction among the different magnitude scales. Thus they are all simply plotted on a $\log r$ versus $M$ diagram, as in Fig. 1 .

\section{The seismic energy density: a general metric}

While $M$ and $r$ are useful parameters for comparing and relating the various hydrologic responses, it would be more convenient if we could replace these two parameters with a single parameter to relate the responses. Ideally this parameter would be a physical quantity that can be measured in laboratories, and hence could provide a useful tie between field observations and laboratory measurements. The parameter 'seismic energy density', defined as the maximum seismic energy available in a unit volume to do work on rock or sediment, may serve this purpose. This is because it may be easily estimated from $M$ and $r$ (equation 2) and, at the same time, may be compared with laboratory results on the dissipated energy required to initiate pore pressure change and liquefaction in saturated sediments. The seismic energy density $e$ is defined and given by (e.g., Lay \& Wallace 1995)

$e=\frac{1}{2} \sum_{i} \frac{\rho}{T_{i}} \int v_{i}(t)^{2} \mathrm{~d} t$

where $\rho$ is density, and $T_{i}$ and $\nu_{i}$ are the period and particle velocity of the $i$ th mode, and the sum is taken over all 
modes for ground motion. For an earthquake of magnitude $M$, the seismic energy density $e$ at a distance $r$ from the earthquake source may be estimated from the empirical relation (Wang 2007)

$\log r=0.48 M-0.33 \log e-1.4$,

where $r$ is in $\mathrm{km}$ and $e$ in $\mathrm{J} \mathrm{m}^{-3}$. This relation implies that contours of constant $e$ plot as straight lines on a log $r$ versus $M$ diagram - these are added to Fig. 1. The seismic energy density is approximately proportional to the square of the peak ground velocity (Wang et al. 2006) which in turn is proportional to the dynamic strain (e.g., Brodsky et al. 2003), and thus provides a convenient and physically meaningful metric to relate and compare the various hydrologic responses.

Figure 1 shows that certain hydrologic responses require much greater seismic energy density (e.g., liquefaction, mud volcanoes) than others (e.g., well level changes, earthquake triggering). On the other hand, each type of hydrologic response spans over four or more orders of magnitude of the seismic energy density values. Scatter may be expected for two reasons. First, if triggering is a threshold process, then for all distances up to the threshold we might expect triggering to be possible. Second, because the hydro-mechanical properties of rocks and sediments are greatly different, the range of sensitivity to seismic shaking may be large. Thus, for any specific hydrologic response to occur, less seismic energy density is required at sites underlain by sediments or rocks more sensitive to seismic disturbances than at sites underlain by less sensitive rocks or sediments. Without a priori knowledge of the seismic sensitivity of the rocks and sediments at a given site, we may compare the different hydrologic responses by focusing on the threshold seismic energy density, i.e., the lower bound of the seismic energy density required to initiate a specific hydrological response in the most sensitive materials. With this simplification, Fig. 1 reveals that different hydrologic responses are bounded by different threshold seismic energy densities. Thus liquefaction, mud volcanoes and streamflow increases are bounded by the contour with $e \sim 10^{-1} \mathrm{~J} \mathrm{~m}^{-3}$; temperature changes in hot springs are bounded by the contour with $e \sim 10^{-2} \mathrm{~J} \mathrm{~m}^{-3}$, and most sustained groundwater changes are bounded by the contour with $e \sim 10^{-3} \mathrm{~J} \mathrm{~m}^{-3}$. An exception for the sustained water-level change is a data point that falls on a contour of $e \sim 10^{-4} \mathrm{~J} \mathrm{~m}^{-3}$ (Fig. 1). This data point represents the response at a well installed in fractured granite (Brodsky et al. 2003), which appears to be particularly sensitive to seismic disturbances (Woodcock \& Roeloffs 1996).

Geysers have long been known to be particularly sensitive to earthquakes, as manifested by changes in the time interval between eruptions (Ingebritsen \& Rojstaczer 1993). Some geysers in the Yellowstone National Park, for example, have responded to seismic energy density as small as $10^{-3} \mathrm{~J} \mathrm{~m}^{-3}$ (Fig. 1; see also Husen et al. 2004). Given the limited number of data, however, we are unable to confirm whether an $M$ versus $\log r$ relationship may also apply to geysers.

Triggered seismicity also appears to be particularly sensitive to seismic disturbances and may respond to $e$ as small as $10^{-4} \mathrm{~J} \mathrm{~m}^{-3}$ (Fig. 1; Brodsky \& Prejean 2005; Hill \& Prejean 2007). In their study of triggered earthquakes at Long Valley, California, following the 2004 Denali earthquake in Alaska, Brodsky \& Prejean (2005) showed that the early arriving $30 \mathrm{~s}$ surface waves triggered local seismicity, while high-frequency seismic waves with comparable cumulative seismic energy density from regional events did not. As a consequence, Brodsky and Prejean dismissed seismic energy density as a threshold for triggering earthquakes because of the timing of the triggered events. Brodsky \& Prejean (2005) also noted that these observations imply that low-frequency seismic waves may be more effective in triggering seismicity. In this regard, it is interesting to note that low-frequency seismic waves may also be more effective in causing coseismic water-level changes and liquefaction (Wong \& Wang 2007) and triggered eruption of mud volcanoes (Manga et al. 2009).

It is important to note that the question whether all triggered seismicity is a hydrological phenomenon is a matter of active debate (e.g., Hill 2008) and it is likely that some triggered earthquakes are not caused by earthquakeinduced re-distribution of pore pressure. Regardless of a clear hydrologic connection, triggered earthquakes by large $(M>9)$ earthquakes may be global (e.g., West et al. 2005; Velasco et al. 2008). Anti-triggering, that is suppression of small earthquakes, may also occur (Okubo \& Wolfe 2008).

Part of the differences in the threshold energy between different hydrological responses may be a result of incomplete data. For example, the data for hot spring temperature come from a single hot spring in Japan (Mogi et al. 1989); thus it is not unlikely that, when more hot springs are studied, the lower bound for the earthquake-induced temperature change in hot springs may become lower than $10^{-2} \mathrm{~J} \mathrm{~m}^{-3}$. On the other hand, most other data summarized in Fig. 1 are abundant, come from a wide range of geological settings, and thus the differences in the threshold energy may be significant.

\section{Undrained consolidation}

Earthquake engineers have long regarded undrained consolidation as the primary mechanism for pore pressure buildup and liquefaction in saturated sediments (National Science Council 1985). Laboratory experiments have demonstrated that the initiation of liquefaction by this mechanism requires a minimum dissipated energy density of $30 \mathrm{~J} \mathrm{~m}^{-3}$ (e.g., Green \& Mitchell 2004; Wang 2007). This required minimum energy density, however, is more 
than $10^{2}$ times greater than the seismic energy density at the threshold distance for liquefaction in the field (Fig. 1).

Another interesting contradiction between the hypothesis of undrained consolidation and far-field observations arises from the changes of groundwater level. Results from laboratory experiments show that a dissipated energy density of $0.1-10 \mathrm{~J} \mathrm{~m}^{-3}$ is required to initiate undrained consolidation in saturated sediments (e.g., Ishihara 1996). This is more than two orders of magnitude greater than the seismic energy density at the threshold distance for sustained groundwater-level changes, i.e., $10^{-3} \mathrm{~J} \mathrm{~m}^{-3}$ (Fig. 1).

Thus it is clear that the mechanism of undrained consolidation may only account for a fraction of the documented liquefaction and groundwater level changes in the field. For liquefaction that occurs at $e<30 \mathrm{~J} \mathrm{~m}^{-3}$ and sustained pore-pressure changes that occur at distances beyond the bounds for undrained consolidation, a different mechanism is required.

\section{Changes in permeability}

Several mechanisms besides undrained consolidation have been proposed to explain hydrologic responses; these include the static poroelastic strain associated with fault displacement (Wakita 1975; Muir-Wood \& King 1993; Quilty \& Roeloffs 1997) and an enhanced permeability of the shallow crust by the dynamic strains associated with seismic waves (Mogi et al. 1989; Rojstaczer et al. 1995; Brodsky et al. 2003; Wang et al. 2004a,b). At distances beyond the near field, static poroelastic strain is so small that it cannot easily account for the large amplitude of the observed hydrologic changes (Rojstaczer et al. 1995; Manga \& Wang 2007). Furthermore, the model often has difficulty in explaining the sign of the observed groundwater-level changes (Roeloffs 1998; Wang et al. 2001; Koizumi et al. 2004) and the persistent streamflow increases in response to multiple earthquakes of different mechanisms and orientations (Manga et al. 2003).

Dynamic strain by itself cannot lead to sustained hydrologic changes, but it can dislodge blockage from fractures and thereby enhance permeability of the shallow crust and to cause re-distribution of pore pressure (Mogi et al. 1989; Roeloffs 1998; Brodsky et al. 2003; Elkhoury et al. 2006, 2009). Mogi et al. (1989) first suggested that seismic waves may dislodge obstacles from passageways feeding hot springs to enhance flow and to cause coseismic increases in hot spring temperature. The same mechanism was used to explain sustained changes in groundwater level (Roeloffs 1998; Brodsky et al. 2003; Wang \& Chia 2008) and increased stream discharge (Rojstaczer et al. 1995; Wang et al. 2004a,b) after large earthquakes. Changes in the eruption frequency of geysers can also be caused by changes in permeability of the conduit and/or surrounding matrix (Ingebritsen \& Rojstaczer 1993). As the permeability of the conduit is very high, changes in the matrix permeability that governs conduit recharge are more likely (Ingebritsen \& Rojstaczer 1993; Manga \& Brodsky 2006). Elkhoury et al. (2006) documented distinct transient shifts in the phase of the tidal response of water level in wells and interpreted these phase shifts in terms of an enhanced permeability caused by earthquakes. The magnitude of this enhancement increases with increased peak ground velocity, i.e., with increased seismic energy density. Other authors (e.g., Roeloffs 1998) also noticed that the amplitude of the sustained groundwater-level change at a given well increases in proportion to the increased peak ground velocity. These relations to peak ground velocity may be expected since greater seismic energy (more rigorous shaking) may clear more blockage from fluid passageways, resulting in a greater increase in permeability and more efficient redistribution of pore pressure. Taken together, it appears that enhanced permeability in the shallow crust during earthquakes may be a viable mechanism for a broad spectrum of hydrologic responses that occur in the intermediate and far fields.

A wide range of experimental studies confirm that timevarying fluid flow can change permeability by dislodging particles or breaking up aggregates of colloidal pore-blocking particles (e.g., Cleasby et al. 1963; Bai \& Tien 1997; Bergendahl \& Grasso 2000; Gao et al. 2004). This process also occurs in the unsaturated zone (e.g., Saiers \& Lenhart 2003). Elkhoury et al. (2009) documented transient increases in permeability in the laboratory following the application of time-varying pore pressure gradients at seismic frequencies. They attributed the changes in permeability to breaking up flocs of small particles. Liu \& Manga (2009) applied time-varying stresses under undrained conditions and documented a permeability decrease in the laboratory - an affect they attribute to both particle redistribution within fractures and consolidation of their laboratory sample to reduce the aperture of fractures. In sum, lab experiments confirm that dynamic stresses and time-varying flow can change permeability, and both permeability increases and decreases may be possible.

It remains to be shown that seismic waves with energy densities as small as $\sim 10^{-4} \mathrm{~J} \mathrm{~m}^{-3}$ can still change permeability. While direct measurement is not yet available, indirect estimate may be obtained from field observation. The 2002 M7.9 Denali earthquake, for example, enhanced groundwater flow in Iowa, some $5000 \mathrm{~km}$ away, to such an extent that colloidal particles were flushed out of local aquifers and discolored well water (Prior et al. 2003). Referring to Fig. 1, this event occurred at a seismic energy density of $\sim 10^{-4} \mathrm{~J} \mathrm{~m}^{-3}$.

Thus, starting at a threshold energy density of $\sim 10^{-4} \mathrm{~J} \mathrm{~m}^{-3}$, seismic waves may dislodge minute clogs 
from fractures to enhance permeability and redistribute pore pressure, triggering seismicity and causing groundwater-level to change in the most sensitive wells. Increasing seismic energy density may remove larger blockages from fractures to allow more efficient groundwater flow. At $10^{-3}$ to $10^{-1} \mathrm{~J} \mathrm{~m}^{-3}$, enhanced permeability may be so effective to cause widespread changes in groundwater level in less sensitive wells, changes in geysers eruption frequency and increases in hot spring temperature.

Continued increases in pore pressure and removal of grains act to degrade sediment stiffness. At a seismic energy density of $10^{-1} \mathrm{~J} \mathrm{~m}^{-3}$, some sensitive sediments may be so weakened to start consolidating. At higher seismic energy density, consolidation and pore-pressure increase may occur in less sensitive sediments. This energy density, though not large enough to induce sediment liquefaction, nonetheless may move the sediments towards a critical state so that they may become liquefied if an additional increment of pore pressure becomes available to push the sediment over the liquefaction limit. We suggest that this additional increment of pore pressure may become available during an earthquake-induced re-distribution of pore pressure from a nearby source, connected by an enhanced permeability, and thus initiates liquefaction in critically pressurized sediments. In such cases, a time delay between the earthquake and the occurrence of liquefaction may occur, as required by the diffusion of pore pressure from the source to the liquefaction site.

In the near field where the seismic energy density exceeds $10 \mathrm{~J} \mathrm{~m}^{-3}$, undrained consolidation may raise pore pressure to the lithostatic limit, directly causing liquefaction. In this case, there should be little delay between the occurrence of liquefaction and earthquake. Earthquakeenhanced permeability must also occur in the near field, but its hydrologic effects in the near field may be obscured by those effects caused by undrained consolidation.

An implication of the above discussion is that the evaluation of earthquake hazards at a specific site may be improved if, in addition to the evaluation of soil property and seismic intensity of the site in isolation, one should also consider the hydrologic heterogeneity in the surrounding area and the effect of pore pressure redistribution due to an earthquake-enhanced permeability that connects the site to nearby pore-pressure sources.

\section{Why do magmatic and mud eruptions have the same threshold distance?}

In Fig. 1 we included another example of a geofluid that responded to earthquakes: the triggered eruption of magmatic volcanoes. The examples included in Fig. 1 include only eruptions triggered within days (e.g., Linde \& Sacks 1998). We do not include delayed triggered eruptions (e.g., Hill et al. 2002; Marzocchi 2002; Walter \& Ame- lung 2007) as these are less straightforward to establish as triggered events (Eggert \& Walter 2009). The mechanism(s) responsible for magmatic eruption are more difficult to identify than the mechanisms for mud volcano eruption as there are a greater number of thermal and mechanical processes that operate in magmatic volcanoes. It is therefore interesting that, on a $M$ versus $\log r$ diagram (Fig. 1), the documented triggered eruptions of the magmatic volcanoes show the same threshold distance as the triggered eruptions of mud volcanoes. It is enigmatic why the two types of eruptions, with great differences in many ways, would require the same threshold seismic energy to be triggered.

Despite the obvious differences between these two types of eruptions, there are several processes and properties shared by both magmatic and mud volcanoes, including the buoyancy provided by exsolved gases, the fluidization or liquefaction of erupted materials, and an overpressured source (Manga et al. 2009). Could a permeability change, a process proposed for the occurrence of liquefaction and mud volcanism at the threshold distance, also play a role for the occurrence of magmatic eruption at the threshold distance?

Magma chambers can become heterogeneous and stratified, as new batches of magma are injected in the magma chamber, and existing magmas differentiate and/or solidify. The volume change upon solidification, about $10 \%$ for typical magmas, will lead to significant changes in pressure in the remaining melt. Owing to the much larger viscosity of silicate melts compared to water, the hydraulic diffusion time needed for pore pressure to re-equilibrate will be correspondingly longer. If the interconnected network of crystals in the solidifying magma the so-called 'mush' - is disrupted or broken by the earthquake, the much larger permeability afforded by fractures will allow for pore pressure to be redistributed much more rapidly. Deeper and pressurized sources may become connected to shallower, critically pressurized regions via such earthquake-enhanced permeability. Re-distribution of pressure through the diffusion of the gas or liquid phase may occur and may push one part of the chamber beyond a critical state leading to eruption. This mechanism may explain why the eruptions of triggered magmatic volcanoes and mud volcanoes require the same seismic energy density to be triggered - a similar energy may be required to disrupt a magmatic mush and a dense sediment. These ideas, of course, are highly speculative and may be difficult to test in the field. At the laboratory scale, however, the energy density required to disrupt a range of materials can be measured. Sumita \& Manga (2008) showed that the viscosity of the liquid phase in dense, packed suspensions does not affect the threshold strain amplitudes needed to change pore pressure (Dobry et al. 1982) or rheology. 


\section{DISCUSSION, CONCLUSIONS, AND OUTLOOK}

The hydrologic responses we compile occurred mostly in the shallow subsurface ( $<1 \mathrm{~km}$ depth), except for mud volcanic eruptions and triggered earthquakes which occurred at depths of many $\mathrm{km}$. The low seismic energy density required at the threshold distances for these responses means that the dynamic permeability enhancement would occur under very low effective stress, that in turn means that they either occur close to the earth's surface or in highly overpressured portions of the crust.

Despite the advances made thus far, much remains to be explored in the hydrologic responses to earthquakes. Two poorly explored aspects include the effect of faulting style and fault rupture directivity. Since the distribution of seismic energy in the near field depends on the style of faulting, the directivity of rupture, and the distance to the ruptured fault, we may expect such dependency to show up in the distribution of the hydrologic responses. Thus the empirical relation among the seismic energy density, earthquake magnitude and hypocentral distance shown in this paper (also Wang 2007) can only be regarded as a first-order approximation. The spatial pattern of changes in streamflow (e.g., Muir-Wood \& King 1993 ) and changes in water level in wells (e.g., Wakita 1975; Jonsson et al. 2003) have been documented (for some cases) to vary with the pattern of static coseismic strain. Part of the reason for our present emphasis on magnitude and distance is that these two parameters are the most easily available, especially for historical earthquakes. Given the recent advances in strong-motion seismology and hydrologic monitoring of groundwater in earthquake prone regions, it should be straightforward to study the dependence of hydrologic responses on the directivity of rupture and on the style of faulting. The result of such efforts can provide important constraints on models on the hydrologic responses in the near- and intermediate-field.

The triggering mechanism for the various hydrologic responses remains intriguing. Interpretations need to be quantitative so they can be tested against experimental measurement. The hypothesis that seismic waves can enhance the permeability of the upper crust has long been proposed (e.g., Rojstaczer et al. 1995; Roeloffs 1998; Brodsky et al. 2003; Elkhoury et al. 2006; Wang \& Chia 2008). However, the mechanism that causes such an enhancement, i.e., how a transient wave may cause a sustained increase in permeability, remains enigmatic. More laboratory experiments (such as those in Elkhoury et al. 2009; Liu \& Manga 2009) are needed to isolate different factors and to identify the responsible mechanism or mechanisms. Theoretical studies are needed to explain the experimental results. Finally, field studies are needed to verify or to reject the various hypotheses as explanations for the natural phenomena.

A surprising finding is that some earthquake-induced water-level changes may be caused by $S$-waves and Love waves (e.g., Wang et al. 2009). Such changes are inconsistent with the current understanding that in the far field only Rayleigh waves that involve changes in volumetric strain can cause water-level changes (Cooper et al. 1965; Liu et al. 1989; Manga \& Wang 2007). It is, however, expected that $\mathrm{S}$-waves and Love waves generate volumetric strains in an anisotropic poroelastic medium (Wang 2000; Brodsky et al. 2003), but quantitative tests are required to demonstrate the validity of the hypothesis. One such test is to deploy a network of broadband stations near the epicenter of an earthquake and to determine the three-dimensional strain tensors at the wells, from which the volumetric strain, if any, can be associated with $S$ - or Love waves.

The frequency dependence of liquefaction (e.g., Wong \& Wang 2007) and triggered seismicity (Brodsky \& Prejean 2005) may provide insight into their mechanisms. However, the results from field and laboratory studies thus far are in conflict. On the one hand, laboratory results show little frequency-dependence of deformation under cyclic shear strain (Yoshimi \& Oh-Oka 1975; Sumita \& Manga 2008); on the other hand, in situ evidence from seismically instrumented sites show an association of liquefaction and triggered seismicity with low-frequency ground motions (e.g., Brodsky \& Prejean 2005; Youd \& Carter 2005; Holzer \& Youd 2007; Wong \&Wang 2007). Future research, including in situ, laboratory, and theoretical work, is required to explain these differences.

Another deficiency in the current study of hydrologic response is a complete absence of the 'site effect' which is known to have a strong influence on the distribution of seismic energy. Attempts to make predictions regarding liquefaction or other hydrologic responses at a particular site require the incorporation of site-specific geologic data. Such information would be needed in a more detailed study of hydrologic responses than those presented in the simplistic compilation shown in Fig. 1.

While it should go without saying that more observations are useful, there is definitely a need for long-term and integrated hydrogeochemical, hydrological, temperature, and deformation measurements. Limited sampling and short time series often limit the ability to test hypotheses and reliably identify hydrologic responses and precursors.

\section{ACKNOWLEDGEMENTS}

MM is supported by the Miller Institute for Basic Research in Science, and NSF grant EAR 0909701. We thank the reviewers for suggestions and comments. 


\section{REFERENCES}

Aki K, Richards PG (1980) Quantitative Seismology. Freeman and Company, New York .

Ambraseys NN (1988) Engineering seismology. Earthquake Engineering Structural Dynamics, 17, 1-105.

Bai R, Tien C (1997) Particle detachment in deep bed filtration. Journal of Colloid and Interface Science, 186, 307-17.

Bardet JP, Kapuskar M (1993) Liquefaction sand boil in San Francisco during 1989 Loma Prieta earthquake. Journal of Geotechnical Engineering, 119, 543-62.

Beresnev IA, Johnson PA (1994) Elastic-wave stimulation of oil production: a review of methods and results. Geophysics, 59, 1000-17.

Bergendahl J, Grasso D (2000) Prediction of colloid detachment in a model porous media: hydrodynamics. Chemical Engineering Science, 55, 1523-32.

Bonini M (2009) Mud volcano eruptions and earthquakes in the Northern Apennines and Sicily, Italy. Tectonophysics, 474, 635723.

Briggs RO (1991) Effects of Loma Prieta earthquake on surface waters in Waddell Valley. Water Resources Bulletin, 27, 991-9.

Briggs RC, Troxell HC (1955) Effects of the Arvin-Tehachapi earthquake on spring and stream flow. In: Earthquakes in Kern County (ed. Oakeshott GB). Divisions of Mines Geological Bulletin, California, 171, 81-97.

Brodsky EE, Prejean SG (2005) New constraints on mechanisms of remotely triggered seismicity at Long Valley Caldera. Journal of Geophysical Research, 110, B04302. doi.:10.1029/ 2004JB003211.

Brodsky EE, Roeloffs E, Woodcock D, Gall I, Manga M (2003) A mechanism for sustained groundwater pressure changes induced by distant earthquakes. Journal of Geophysical Research, 108, 2390. doi.: 10.1029/2002JB002321.

Carrigan CR, King GCP, Barr GE, Bixler NE (1991) Potential for water-table excursions induced by seismic events at Yucca Mountain, Nevada. Geology, 19, 1157-60.

Chen JS, Wang C-Y (2009) Rising springs along the Silk Road. Geology, 37, 243-46.

Chigira M, Tanaka K (1997) Structural features and the history of mud volcanoes in Southern Hokkaido, Northern Japan. Journal of the Geological Society of Japan, 103, 781-91.

Cleasby JL, Williamson MM, Baumann ER (1963) Effect of filtration rate changes on quality. Journal of the American Water Works Association, 55, 869-77.

Cooper HH, Bredhoeft JD, Papdopulos IS, Bennnett RR (1965) The response of aquifer- well systems to seismic waves. Journal of Geophysical Research, 70, 3915-26.

D'Alessandro W, Parello F, Velenza M (1996) Gas manifestations on Mount Etna area: historical notices and new geochemical data (1990-1993). Acta Vulcanologia, 8, 23-9.

Davies RJ, Brumm M, Manga M, Rubiandini R, Swarbrick R, Tingay $M$ (2008) The East Java mud volcano (2006-present): an earthquake or drilling trigger? Earth and Planetary Science Letters, 272, 627-38.

Davies EE, Wang K, Thomson RE, Becker K, Cassidy JF (2001) An episode of seafloor spreading and associated plate deformation inferred from crustal fluid pressure transients. Journal of Geophysical Research, 106, 21953-63.

De Brignoli di Brunhoff G (1836) Relazione accademica dell'ultima eruzione accaduta nel vulcanetto aereo cosi detta Salsa di Sassuolo nel modeenese e considerazioni geognostiche intorno alle salse e alle loro cause. Tipografia Torreggiani et Compagno, Reggio, 66 pp.
Delisle G (2005) Mud volcanoes of Pakistan. In: Mud Volcanoes, Geodynamics and Seismicity (eds Martinelli G, Panahi B), pp. 159-69. NATO Science Series, Earth and Environmental Sciences, Vol. 51, Springer, Dordrecht, Netherlands.

Deville E (2008) Mud volcano systems. In: Volcanoes: Formation, Eruptions and Modeling (eds Lewis N, Moretti A), pp. 95-125. Nova publishers, New York.

Dobry R, Ladd RS, Yokel FY, Chung RM, Powell D (1982) Prediction of pore water pressure buildup and liquefactionof sands during earthquakes by the cyclic strain method. NBS Building Science Series, U.S., 138, pp. 150.

Eggert S, Walter TR (2009) Volcanic activity before and after large tectonic earthquakes: observations and statistical significance. Tectonophysics, 471, 14-26.

Elkhoury JE, Brodsky EE, Agnew DC (2006) Seismic waves increase permeability. Nature, 411, 1135-8.

Elkhoury JE, Niemeijer A, Brodsky EE, Marone C (2009) Dynamic stress stimulates flow in fractures. Journal of Geophysical Research, (submitted).

Galli P (2000) New empirical relationships between magnitude and distance for liquefaction. Tectonophysics, 324, 169-87.

Gao B, Saiers JE, Ryan JN (2004) Deposition and mobilization of clay colloids in unsaturated porous media. Water Resources Research, 40, W08602. doi:10.1029/2004WR003189.

Green RA, Mitchell JK (2004) Energy-based evaluation and remediation of liquefiable soils. In: Geotechnical Engineering for Transportation Projects (eds Yegian M, Kavazanjian E), ASCE Geotechnical Special Publication, No. 126, 2, 1961-70.

Guidoboni E (1989) I terremoti prima del Mille in Italia e nell'area mediterranea: Storia, archeologia, sismologia. Instituto Nazionale di Geofisica-Storia Geofisica Ambiente, Bologna, 766 pp.

Hill DP (2008) Dynamic stresses, Coulomb failure, and remote triggering. Bulletin of the Seismological Society of America, 94, 66-92.

Hill DP, Prejean SG (2007) Dynamic Triggering in Treatise of Geophysics, Vol. 4, pp. 293-320. Elsevier, Amsterdam.

Hill DP, Pollitz F, Newhall C (2002) Earthquake-volcano interactions. Physics Today, 55, 41-7.

Holzer TL, Youd TL (2007) Liquefaction, ground oscillation, and soil deformation at the Wildlife Array, California. Bulletin of the Seismological Society of America, 97, 961-76.

Husen S, Taylor R, Smith RB, Healser H (2004) Changes in geyser eruption behavior and remotely triggered seismicity in Yellowstone National Park produced by the 2002 M7.9 Denali Fault earthquake, Alaska. Geology, 32, 537-40.

Ingebritsen SE, Rojstaczer SA (1993) Controls on geyser periodicity. Science, 262, 889-92.

Ishihara K (1996) Soil Behavior in Earthquake Geotechnics. Clarendon Press, Oxford, 350 pp.

Jonsson S, Segall P, Pedersen R, Bjornsson G (2003) Post-earthquake ground movements correlated to pore-pressure transients. Nature, 424, 179-83.

Kayen R, Thompson E, Minasiah D, Collins B, Moss ERS, Sitar N, Carver G (2002) Geotechnical reconnaissance of the November 3, 2002 M7.9 Denali fault earthquake, Earthquake Spectra, Special Issue on the M7.9 Denali Fault Earthquake of 3 November 2002, 1-27.

Kilb D, Gomberg J, Bodin P (2002) Aftershock triggering by complete Coulomb stress changes. Journal of Geophysical Research, 107, 2060. doi: 10.1029/2001JB000202.

King C-Y, Basler D, Presser TS, Evans CW, White LD, Minissale $\mathrm{AD}$ (1994) In search of earthquake-related hydrologic and chemical changes along the Hayward fault. Applied Geochemistry, 9, 83-91. 
King C-Y, Azuma S, Igarashi G, Ohno M, Saito H, Wakita H (1999) Earthquake-related water-level changes at 16 closely clustered wells in Tono, central Japan. Journal of Geophysical Research, 104, 13,073-82.

Kitagawa Y, Koizumi N, Takahashi M, Matsumoyo N, Sato T (2006) Changes in water levels or pressures associated with the 2004 earthquake off the west coast of northern Sumatra (M9.0). Earth Planets Space, 58, 173-79.

Koizumi N, Lai W-C, Kitagawa Y, Matsumoto Y (2004) Comment on "Coseismic hydrological changes associated with dislocation of the September 21, 1999 Chichi earthquake, Taiwan" by Min Lee et al.. Geophysical Research Letters, 31, L13603. doi:10.1029/2004GL019897.

La Via PD (1828) Sur une eruption fangeuse d'un volcan hydroargileux (Salse) de la Sicile. Bulletin des Sciences Naturelles et de Geologie, 13, 33-35.

Lawson AC (1908) The California Earthquake of April 18, 1906, Report of the State Earthquake Investigation Commission, Vol. 1, Carnegie Institution of Washington, Washington DC.

Lay T, Wallace TC (1995) Modern Global Seismology. Academic Press, San Diego.

Lemarchand N, Grasso J-R (2007) Interactions between earthquakes and volcano activity. Geophysical Research Letters, 34, L24303.

Linde A, Sacks IS (1998) Triggering of volcanic eruptions. Nature, 395, 888-90.

Liu W, Manga M (2009) Changes in permeability caused by dynamic stresses in fractured sandstone. Geophysical Research Letters, 36, L20307. doi:10.1029/2009GL039852.

Liu L-B, Roeloffs E, Zheng X-Y (1989) Seismically induced water level fluctuations in the Wali well, Beijing, China. Journal of Geophysical Research, 94, 9453-62.

Manga M (2007) Did an earthquake trigger the May 2006 eruption of the Lusi mud volcano? EOS, 88, 201.

Manga M, Brodsky E (2006) Seismic triggering of eruptions in the far field: volcanoes and geysers. Annual Reviews of Earth Planetary Science, 34, 263-91.

Manga M, Rowland JC (2009) Response of Alum Rock springs to the October 30, 2007 earthquake and implications for the origin of increased discharge after earthquakes. Geofluids, 9, 23750 .

Manga M, Wang C-Y (2007) Earthquake hydrology. In: Earthquake Seismology (Ed. Kanamori H), Vol. 4 of Treatise on Geophysics. Elsevier, Amsterdam, Ch. 4.10, 293-320.

Manga M, Brodsky EE, Boone M (2003) Response of streamflow to multiple earthquakes and implications for the origin of postseismic discharge changes. Geophysical Research Letters, 30, 1214. doi:10.1029/2002GL016618.

Manga M, Brumm M, Rudolph ML (2009) Earthquake triggering of mud volcanoes. Marine and Petroleum Geology, 26, 1785-98. doi:10.1016/j.marpetgeo.2009.01.019.

Martinelli G, Bassignani A, Ferrari G, Finazzi PB (1989) Predicting earthquakes in Northern Appenines: recent developments in monitoring of Radon 222, Proceedings of the 4th International Symposium on the Analysis of Seismicity and Seismic Risk, Bechyne Castle, Czechoslovakia, 4-9 September 1989, 192-208.

Marzocchi W (2002) Remote seismic influence on large explosive eruptions. Journal of Geophysical Research, 107, 2018. doi:10.1029/2001JB000307.

Matsumoto N, Kitagawa G, Roeloffs EA (2003) Hydrological response to earthquakes in the Haibara well, central Japan - I. Water level changes revealed using state space decomposition of atmospheric pressure, rainfall and tidal responses. Geophysical Journal International, 155, 885-98.
Mazzini A, Svensen H, Akhmanov GG, Aloisi G, Planke S, Malthe-Sorenssen A, Istadi B (2007) Triggering and dynamic evolution of the LUSI mud volcano, Indonesia. Earth and Planetary Science Letters, 261, 375-88.

McPherson RC, Dengler LA (1992) The Honeydew earthquake, August 12, 1991. California Geology, 31-9.

Mellors R, Kilb D, Aliyev A, Gasanov A, Yetirmishli G (2007) Correlations between earthquakes and large mud volcano eruptions. Journal of Geophysical Research, 112, B04304.

Mogi K, Mochizuki H, Kurokawa Y (1989) Temperature changes in an artesian spring at Usami in the Izu Peninsula (Japan) and their relation to earthquakes. Tectonophysics, 159, 95-108.

Montgomery DR, Manga M (2003) Streamflow and water well responses to earthquakes. Science, 300, 2047-49.

Montgomery DR, Greenberg HM, Smith DT (2003) Streamflow response to the Nisqually earthquake. Earth Planetary Science Letters, 209, 19-28.

Muir-Wood R, King GCP (1993) Hydrological signatures of earthquakes strain. Journal of Geophysical Research, 98, 22.

National Research Council (1985) Liquefaction of Soils during Earthquakes. Washington, D.C., 240 pp.

Okubo PG, Wolfe CJ (2008) Swarms of similar long-period earthquakes in the mantle beneath Mauna Loa Volcano. Journal of Volcanology and Geothermal Research, 178, 787-94.

Pierepiekarz MR, Ballantyne DB, Hamberger RO (2001) Damage report from Seattle. Civil Engineering, American Society of Civil Engineering, 71, 78-83.

Prior JC, Boekhoff JL, Howes MR, Libra RD, VanDorpe PE (2003) Iowa's Groundwater Basics. Iowa Department of Natural Resources, Iowa City, $92 \mathrm{pp}$.

Quilty EG, Roeloffs EA (1997) Water-level changes in response to the 20 December 1994 earthquake near Parkfield, California. Bulletin of the Seismological Society of America, 87, 310-7.

Quilty EG, Farrar CD, Galloway DL, Hamlin SN, Laczniak RJ, Roeloffs EA, Sorey ML, Woodcock DE (1995) Hydrologic effects associated with the January 14, 1994 Northridge, California, earthquake, USGS Open File Report 95-813.

Rajendran K, Rajendran CP, Thakkar M, Tuttle MP (2001) The 2001 Kutch (Bhuj) earthquake: coseismic surface features and their significance. Current Science, 80, 1397-405.

Roeloffs EA (1998) Persistent water level changes in a well near Parkfield, California, due to localand distant earthquakes. Journal of Geophysical Research, 103, 869-89.

Roeloffs E, Danskin WR, Farrarr CD, Galloway DL, Hamlin SN, Quilty EG, Quinn HM, Schaefer DH, Sorey ML, Woodcock DE (1995) Hydrologic effects of the June 28, 1992 Landers earthquake. U.S. Geological Survey Open File Report 95-42.

Roeloffs EA, Sneed M, Galloway DL, Sorey ML, Farrar CD, Howle JF, Hughes J (2003) Water-level changes induced by local and distant earthquakes at Long Valley caldera, California. Journal of Volcanology and Geothermal Research, 127, 269-303.

Rojstaczer S, Wolf S, Michel R (1995) Permeability enhancement in the shallow crust as a cause of earthquake-induced hydrological changes. Nature, 373, 237-9.

Rothaus RM, Reinhardt E, Noller J (2004) Regional consideration of coastline change, tsunami damage and recovery along the southern coast of the Bay of Izmit. Natural Hazards, 31, 23352.

Rowland JC, Manga M, Rose TP (2008) The influence of poorly interconnected fault zone flow paths on spring geochemistry. Geofluids, 8, 93-101.

Rukavickova L, Hanzl P (2008) Mud volcanoes in the Khar Angalantyn Nuruu, NW Gobi Altay, Mongolia as manifestation of recent seismic activity. Journal of Geosciences, 53, 181-91. 
Saiers JE, Lenhart JJ (2003) Colloid mobilization and transport within unsaturated porous media under transient-flow conditions. Water Resources Research, 39, 1019. doi:10.1029/ 2002WR001370.

Sato T, Sakai R, Furuya K, Kodama T (2000) Coseismic spring flow changes associated with the 1995 Kobe earthquake. Geophysical Research Letters, 27, 1219-22.

Sato T, Matsumoto N, Kitagawa Y, Koizumi N, Takahashi M, Kuwahara $\mathrm{Y}$, Ito $\mathrm{H}$, Cho $\mathrm{A}$, Satoh $\mathrm{T}$, Ozawa $\mathrm{K}$, Tasaka S (2004) Changes in water level associated with the 2003 Tokachi-oki earthquake. Earth Planets Space, 56, 395-400.

Seed HB, Lee KL (1966) Liquefaction of saturated sands during cyclic loading. Journal of Soil Mechanics, Foundation Division, 92, 105-34.

Sil S, Freymueller JT (2006) Well water level changes in Fairbanks, Alaska, due to the great Sumatra-Andaman earthquake. Earth Planets Space, 58, 181-4.

Silver PG, Wakita H (1996) A search for earthquake precursors. Science, 271, 77-8.

Snead RE (1964) Mud volcanoes of Baluchistann, West Pakistan. The Geographical Review, 54, 546-60.

Sumita I, Manga M (2008) Suspension rheology under oscillatory shear and its geophysical implications. Earth and Planetary Science Letters, 269, 467-76.

Trabucco G (1895) Terremoto della Romagna Toscana del 4 Settembre 1895. Bollettino Societa Geologica Italiana, 14, 284-6.

Velasco AA, Hernandez S, Parsons T, Pankow K (2008) Global ubiquity of dynamic earthquake triggering. Nature Geoscience, 1, 375-9.

Vorhis RC (1968) Effects outside Alaska, in The Great Alaska of 1964, Hydrology. National Academy of Science Publication 1603, Washington DC, 140-89.

Wakita H (1975) Water wells as possible indicators of tectonic strain. Science, $189,553-5$.

Waller R (1966) Effects of the March 1964 Alaska earthquake on the hydrology of the Anchorage area, US Geological Survey Professional Paper 544B.

Walter TR, Amelung F (2007) Volcanic eruptions following $M>9$ megathrust earthquakes: Implications for the SumatraAndaman volcanoes. Geology, 35, 539-42.

Wang H (2000) Theory of Linear Poroelasticity with Applications to Geomechanics. Princeton University Press, Princeton, $287 \mathrm{pp}$.

Wang C-Y (2007) Liquefaction beyond the near field. Seismological Research Letters, 78, 512-7.
Wang C-Y, Chia Y (2008) Mechanism of water level changes during earthquakes: Near field versus intermediate field. Geophysical Research Letters, 35, L12402. doi:10.1029/2008GL034227.

Wang C-Y, Manga M (2010) Earthquakes and Water, Vol. 114. Lecture Notes in Earth Sciences, Springer, Berlin. 249 pp. ISBN: 978-3-642-00809-2

Wang C-Y, Cheng L-H, Chin C-V, Yu S-B (2001) Coseismic hydrologic response of an alluvial fan to the 1999 Chi-Chi earthquake, Taiwan. Geology, 29, 831-4.

Wang C-Y, Manga M, Dreger D, Wong A (2004a) Streamflow increases due to the rupturing of hydrothermal reservoir - evidence from the 2003 San Simeon, California, Earthquake. Geophysical Research Letters, 31, L10502. doi:10.1029/ 2004GL020124.

Wang C-Y, Wang C-H, Manga M (2004b) Coseismic release of water from mountains: Evidence from the $1999(\mathrm{Mw}=7.5)$ Chi-Chi, Taiwan, earthquake. Geology, 32, 769-72.

Wang C-Y, Wong A, Dreger DS, Manga M (2006) Liquefaction limit during earthquakes and underground explosions: Implications on ground-motion attenuation. Bulletin of the Seismological Society of America, 96, 355-63.

Wang C-Y, Chia Y, Wang PI, Dreger D (2009) Role of S waves and Love waves in coseismic permeability enhancement. Geophysical Research Letters, 36, L09404. doi:10.1029/2009GL 037929.

West M, Sanchez JJ, McNutt SR (2005) Periodically triggered seismicity at Mount Wrangell, Alaska, after the Sumatra earthquake. Science, 308, 1144-6.

Wong A, Wang C-Y (2007) Field relations between the spectral composition of ground motion and hydrological effects during the 1999 Chi-Chi (Taiwan) earthquake. Journal of Geophysical Research, 112, B10305.

Woodcock D, Roeloffs E (1996) Seismically-induced water level oscillations in a fractured-rock aquifer well near Grants Pass, Oregon. Oregon Geology, 58, 27-33.

Yoshimi Y, Oh-Oka H (1975) Influence of degress of shear stress reversal on the liquefaction potential of saturated sand.. Soils and Foundations (Japan), 15, 27-40.

Youd TL, Carter BL (2005) Influence of soil softening and liquefaction on spectral accelerations. Journal of Geotechnical and Geoenvironmental Engineering, 131, 811-25.

Yu M-S, Shieh B-C, Chung YT (2000) Liquefaction induced by Chi-Chi earthquake on reclaimed land in central Taiwan. SinoGeotech, 77, 39-50 (in Chinese). 